\title{
KEKUATAN PEMBUKTIAN SERTIFIKAT HAK PEMAKAIAN TEMPAT USAHA (SHPTU) SEBAGAI JAMINAN UTANG (CONTOH KASUS SHPTU PASAR TANAH ABANG BLOK B JAKARTA)
}

\section{Liana P Nugroho, Gunawan Djajaputra}

Fakultas Hukum Universitas Tarumanagara Jakarta, Indonesia

Email: liana_nugroho@yahoo.com,gunawand@fh.untar.ac.id

\begin{abstract}
Abstrak
Sertifikat Hak Pemakaian Tempat Usaha (SHPTU) adalah bukti kepemilikan hak pemakaian tempat usaha di pasar yang wajib dimiliki oleh Pedagang pasar dan memiliki nilai ekonomis yang cukup tinggi diharapkan dapat dijadikan jaminan utang sebagaimana yang dinyatakan dalam Peraturan Dearah Khusus Ibukota Jakarta Nomor 7 Tahun 2018 tentang Pengelolaan dan Pengembangan Usaha Perusahaan Umum Daerah Pasar Jaya, namun faktanya tidak semua Bank bersedia dalam pemberian kredit, Keberatan Bank menerima SHPTU sebagai jaminan utang memiliki alasan yang kuat sebab Tempat Usaha di dalam hukum jaminan kebendaan tidak dikategorikan sebagai benda tidak bergerak yang mana tempat usaha pasar hanya merupakan ijin pemakaian tempat usaha di pasar, oleh karena tidak ada hubungan langsung antara pedagang dengan bendanya (tempat usaha pasar yang dipakainya). SHPTU lahir dari perjanjian pemakaian tempat usaha antara Perusahaan Umum Daerah Pasar Jaya (Perumda Pasar Jaya), Penelitian ini menggunakan metode penelitian normatif yuridis dengan menambahkan unsur empiris dan wawancara, dengan analisis data secara kualitatif. Dari hasil analisis ditarik kesimpulan bahwa SHPTU tidak mempunyai kekuatan hukum yang sama seperti halnya Sertifikat Tanah, walaupun sama-sama bisa dialihkan kepada pihak lain, bahkan tanah dengan Sertifikat hak pakai saja hanya Bank tertentu yang mau menerima sebagai jaminan walaupun jelas dalam Undang-Undang Nomor 4 Tahun 1996 tentang Hak Tanggungan atas Tanah Berserta Benda-Benda yang berkaitan dengan Tanah memperbolehkan hak pakai sebagai jaminan, namun memgingat SHPTU memiliki nilai ekonomis dan dapat dialihkan, maka di harapkan pemerintah dapat segera menjawab kebutuhan para pedagang pasar terhadap adanya suatu hukum jaminan yang dapat mengakomodir SHPTU sebagai jaminan yang setara dengan Sertifikat tanah.
\end{abstract}

Kata Kunci: Kekuatan Pembuktian Sertifikat Hak Pemakaian Tempat Usaha (SHPTU); Jaminan Utang

\footnotetext{
Abstract

Certificate of Right to Use Business Places (SHPTU) is a proof of ownership that a market trader have to own and it has a high economic value that are excepted to be a guarantee object as stated in Special Region Regulation for Jakarta Capital City Number 7 of 2018 concerning Management and Business Development of Pasar

$\begin{array}{ll}\text { How to cite: } & \text { Nugroho, Liana P dan Gunawan Djajaputra (2021) Kekuatan Pembuktian Sertifikat Hak Pemakaian } \\ & \text { Tempat Usaha (Shptu) Sebagai Jaminan Utang (Contoh Kasus Shptu Pasar Tanah Abang Blok B Jakarta). } \\ & 6(7) . \text { http://dx.doi.org/10.36418/syntax-literate.v6i7.3396 } \\ & 2548-1398 \\ \text { E-ISSN: } & \text { Ridwan Institute } \\ \text { Published by: } & \end{array}$
}


Jaya Regional Public Compay, but in fact, not all banks are willing to accept SHPTU as a guarantee object. Only certain bank that are willing to accept it. The bank have a strong reason to objected SHPTU as a guarantee object because in security of law, market place can't be categorized as immovable object. Market places had not fulfilled the constituent contained in Book II of the Civil Kode to be categorized as material right, where as the market places is only a permit to use the places which doesn't give a material right because there is no direct connection between the merchant and the object. SHPTU is created from the agreement to use a places of business the Pasar Jaya Regional Public Company (Perumda Pasar Jaya), market traders and developer. SHPTU is not a material right, its an individual right that have similar constituent with leasing as stipulated in article 1548 of the Civil Code. This thesis uses a juridical normative research method by adding an empirical element, interview and qualitative data analysis. Based on the analysis result, it can be concluded that SHPTU don't have the same strength of proof as the land certificate, although both can be diverted to another party, even land with a right use of certificate only certain banks are willing to accept it as a guarantee although it is clear in Law Number 4 of 1996 concerning Mortgage on Land and Objects that related to land allow to use rights as guarantee. However, considering that SHPTU has economic value and can be diverted it is hoped that the government can immediately respond to the needs of market traders for the security of law that can accommodate SHPTU as a guarantee equivalent to land certificate.

Keywords: Strenght of Proof Certificate of Rights to Use Business Place (SHPTU); dept guarantee

\section{Pendahuluan}

Perkembangan pembangunan kota Jakarta dan pertumbuhan jumlah penduduk yang semakin bertambah mengakibatkan meningkatkan konsumsi masyarakat terhadap barang dengan kebutuhan rumah tangga, juga berpengaruh pada para pengusaha termasuk pedagang pasar. Pasar merupakan bagian dari kehidupan sosial masyarakat yang tumbuh kembangnya disesuaikan dengan kebiasaan norma adat di suatu wilayah, yang kemudian pasar tersebut menjadi sarana kegiatan perekonomian yang menopang dan memfasilitasi kebutuhan masyarakat.

Pasar Tanah Abang Jakarta merupakan salah satu pusat perbelanjaan terbesar di kota Jakarta terutama dalam penjualan pakaian yang menjadi salah satu pusat perhatian masyarakat masa kini, banyaknya pembeli yang datang baik berasal dari dalam maupun luar kota Jakarta ke pusat perbelanjaan Tanah Abang dikarenakan harga yang ditawarkan relatif terjangkau juga produk yang dijual memiliki kualitas yang cukup baik.

Dalam Peraturan Daerah DKI Jakarta Nomor 7 Tahun 2018 tentang Pengelolaan dan Pengembangan Usaha Perusahaan Umum Daerah Pasar Jaya disebutkan bahwa untuk dapat menggunakan tempat-tempat usaha harus mendapatkan ijin pemakaian tempat usaha secara tertulis dari Perusahan Umum Daerah Pasar Jaya agar pemakaian tempat mempunyai hak memakai tempat di pasar. Sertifikat Hak Pemakaian Tempat 
Usaha (SHPTU) adalah bukti kepemilikan hak pemakaian tempat usaha (kios) di pasar yang dimiliki oleh Pedagang pasar. SHPTU memiliki nilai ekonomis yang cukup tinggi. Oleh karenanya diharapkan SHPTU dan Perjanjian Pemakaian Tempat Usaha (PPTU) dapat dijadikan jaminan utang (Khairi \& Roestamy, 2017).

Berdasarkan Peraturan Daerah Provinsi Daerah Khusus Ibukota Jakarta Nomor 7 Tahun 2018 tentang Pengelolaan dan Pengembangan Usaha Perusahaan Umum Daerah Pasar Jaya yang menyatakan bahwa SHPTU adalah bukti kepemilikan hak pemakaian tempat usaha yang berlaku untuk jangka waktu paling lama 20 (dua puluh) tahun yang bisa dijadikan jaminan utang. Ketentuan tersebut menjadi titik cerah bagi pedagang pasar yang menginginkan agar SHPTU dapat dijadikan jaminan utang. Namun dalam prakteknya tidak demikian, SHPTU hanya diterima bank sebagai jaminan tambahan bukan jaminan pokok, tidak seperti Sertipikat Tanah atau Tanah dan Bangunan dapat dijadikan sebagai jaminan utang pokok, hal ini tidak seperti sebagaimana yang diinginkan Perumda Pasar Jaya maupun ketentuan dalam Peraturan Daerah Provinsi Daerah Khusus Ibukota Jakarta Nomor 7 Tahun 2018. Hal demikian menjadi kerugian yang nyata bagai pedagang pasar untuk memperoleh SHPTU, pedagang harus mengeluarkan dana yang sangat tinggi.

Berdasarkan uraian latar belakang diatas, maka penulis tertarik untuk mengkaji lebih lanjut megenai permasalahan ini secara komprehensif dan menuangkannya dalam bentuk tesis dengan judul: "Kekuatan Pembuktian Sertifikat Hak Pemakaian Tempat Usaha (SHPTU) Sebagai Jaminan Utang (Contoh Kasus SHPTU Pasar Tanah Abang Blok B Jakarta)".

\section{A. Tujuan dan Kegunaan Penelitian}

1. Tujuan Penelitian

Adapun tujuan dari penelitian yang ingin dicapai adalah:

a. Untuk mengetahui dan menganalisis SHPTU di tinjau dari hukum jaminan di Indonesia.

b. Untuk mengetahui dan menganalisis kekuatan hukum pembuktian SHPTU dan Sertipikat Tanah sebagai jaminan utang.

2. Kegunaan Penelitian

a. Secara Teoritis

Kegunaan dari penelitian ini adalah untuk memberikan sumbangan pemikiran dan kontribusi bagi pengembangan Ilmu Hukum Bisnis, Pemerintah Daerah Khusus Ibukota Jakarta (DKI Jakarta), DPRD DKI Jakarta dan Kenotariatan.

b. Secara Praktis

Penelitian ini dapat berguna untuk memberikan masukan kepada praktisi dan lembaga perbankan terkait SHPTU sebagai jaminan utang.

\section{Metode Penelitian}

Metode penelitian yang digunakan dalam penelitian ini adalah metode penelitian normatif menambahkan unsur empiris. Soerjono Soekanto, mengemukakan bahwa 
pendekatan yuridis normatif merupakan penelitian hukum yang dilakukan dengan cara meneliti bahan pustaka atau data sekunder sebagai bahan dasar untuk diteliti dengan cara mengadakan penelusuran terhadap peraturan-peraturan dan literatur-literatur yang berkaitan dengan permasalahan yang diteliti (Soerjono Soekanto dan Sri Mamudji, 2019). Metode penelitian ini digunakan karena dalam penelitian hukum normatif yang diteliti hanya bahan pustaka atau data sekunder terdiri dari (Soerjono Soekanto, 2019): Penelitian hukum pada dasarnya merupakan suatu kegiatan ilmiah yang didasarkan pada metode sistematika dan pemikiran tertentu, yang bertujuan untuk mempelajari satu atau beberapa gejala hukum tertentu dengan jalan menganalisisnya, serta melakukan pemeriksaan secara mendalam atas fakta hukum tersebut untuk kemudian mengusahakan suatu pemecahan atas permasalahan-permasalahan yang timbul di dalam gejala yang bersangkutan. Berdasarkan judul yang dikaji oleh penulis, maka metode penelitian yang akan digunakan adalah sebagai berikut:

\section{Jenis Penelitian}

Metode penelitian yang digunakan dalam penelitian ini adalah metode penelitian normatif menambahkan unsur empiris. Metode penelitian ini digunakan karena dalam penelitian hukum normatif yang diteliti hanya bahan pustaka atau data sekunder terdiri dari:

a) Bahan hukum Primer yatiu baha-nahan hukum yang mengikat dan terdiri dari norma atau kaedah dasar, yakni Pembukaan UUD 1945, Peraturan Dasar, yakni batang Tubuh UUD 1945 dan Ketetapan-ketetapan MPR, peraturan perundangan seperti undang-undang dan peraturan yang setaraf, keputusan presiden dan peraturan yang setaraf. Keputusan Menteri dan peraturan yang setaraf, peraturan-peraturan daerah, bahan hukum yang dikodifikasikan, yurisprudensi, traktat, bahan hukum dari zaman penjajahan yang hingga kini berlaku.

b) Bahan hukum sekunder yaitu bahan hukum yang memberikan penjelasan mengenai bahan hukum primer, misalnya rancangan undang-undang, hasil-hasil penelitian, hasil karya dari kalangan hukum.

c) Bahan hukum tertier yakni bahan yang memberikan petunjuk maupun penjelasan terhadap bahan hukum primer dan sekunder, contohnya adalah kamus, ensiklopedi, indeks kumulatif.

d) Bahan Non-Hukum, yaitu wawancara pihak-pihak yang terkait.

Pengumpulan data dilakukan melalui studi kepustakaan, studi kepustakaan dilakukan dengan mengacu pada buku-buku dan peraturan-peraturan dari perpustakaan.

Penelitian ini juga dilengkapi dengan praktek penerapan hukum di masyarakat, yang dalam hal ini bisa didapat dari pedagang pasar Tanah Abang Blok B, pihak Bank, pihak Perumda Pasar Jaya dan pihak-pihak lain yang berkaitan dengan objek penelitian terkait dengan Sertifikat Hak Pemakaian Tempat Usaha (SHPTU) atas kios sebagai jaminan. 


\section{Sifat Penelitian}

Penelitian ini bersifat deskriptif, yaitu menggambarkan gejala-gejala di lingkungan masyarakat terhadap suatu kasus yang diteliti yakni kepastian hukum terkait perlindungan bagi pemegang SHPTU.

\section{Jenis dan Sumber Data}

Data yang digunakan dalam penelitian ini adalah data sekunder yaitu data yang diperoleh dari kepustakaan. Data sekunder yang dipergunakan adalah data sekunder yang bersifat umum, yaitu data yang berupa tulisan-tulisan, data arsip, data resmi dan berbagai data lain yang dipublikasikan.

\section{Teknik Pengumpulan Data}

Pengumpulan data sekunder dilakukan dengan studi kepustakaan, yang dikumpulkan melalui proses membaca, mempelajari serta mengidentifikasi dan mengklasifikasi bahan tersebut sehingga diperoleh bahan yang relevan dengan permasalahan yang dibahas.

\section{Pendekatan Penelitian}

Pendekatan penelitian merupakan merupakan cara berpikir yang diadopsi peneliti tentang bagaimana desain riset dibuat dan bagaimana penelitian akan dilakukan.

\section{Hasil dan Pembahasan}

\section{A. Kedudukan Sertifikat Hak Pemakaian Tempat Usaha (SHPTU) di Tinjau Dari} Hukum Jaminan

\section{Tinjauan Tentang Hukum Jaminan}

Menurut (Salim \& Nurbani, 2017) hukum jaminan adalah keseluruhan kaidah-kaidah hukum yang mengatur hubungan antara pemberi dan penerima jaminan dalam kaitannya dengan pembebanan jaminan untuk mendapatkan fasilitas kredit. Unsur-unsur yang tercantum di dalam definisi ini adalah:

a. Adanya kaidah hukum

Kaidah hukum dalam bidang jaminan, dapat dibedakan menjadi 2 macam, yaitu kaidah hukum jaminan tertulis dan kaidah hukum jaminan tidak tertulis. Kaidah hukum jaminan tertulis adalah kaidah-kaidah hukum yang terdapat dalam peraturan perundang-undangan, traktat, dan yurisprudensi. Sedangkan kaidah hukum jaminan tidak tertulis adalah kaidah-kaidah hukum jaminan yang tumbuh, hidup, dan berkembang dalam masyarakat. Hal ini terlihat pada gadai tanah dalam masyarakat yang dilakukan secara lisan.

b. Adanya pemberi dan penerima jaminan

Pemberi jaminan adalah orang-orang atau badan hukum yang menyerahkan barang jaminan kepada penerima jaminan. Yang bertindak sebagai pemberi jaminan ini adalah orang atau badan hukum yang membutuhkan fasilitas kredit. Orang ini lazim disebut dengan debitur. Penerima jaminan adalah orang atau badan hukum yang menerima barang jaminan dari pemberi jaminan. Yang bertindak sebagai penerima jaminan ini 
adalah orang atau badan hukum. Badan hukum adalah lembaga yang memberikan fasilitas kredit, dapat berupa lembaga perbankan dan atau lembaga keuangan nonbank.

c. Adanya jaminan

Pada dasarnya, jaminan yang diserahkan kepada kreditur adalah jaminan materiil dan imateriil. Jaminan materiil merupakan jaminan yang berupa hak-hak kebendaan, seperti jaminan atas benda bergerak dan benda tidak bergerak. Jaminan imateriil merupakan jaminan nonkebendaan.

d. Adanya fasilitas kredit

Pembebanan jaminan yang dilakukan oleh pemberi jaminan bertujuan untuk mendapatkan fasilitas kredit dari bank atau lembaga keuangan nonbank. Pemberian kredit merupakan pemberian uang berdasarkan kepercayaan, dalam arti bank atau lembaga keuangan nonbank percaya bahwa debitur sanggup untuk mengembalikan pokok pinjaman dan bunganya. Begitu juga debitur percaya bahwa bank atau lembaga keuangan nonbank dapat memberikan kredit kepadanya.

Dari unsur-unsur tersebut diatas, penulis berpendapat bahwa SHPTU hanya dapat dijaminkan hak pemakaian tempat usahanya saja tidak pada hak kebendaannya karena SHPTU tidak diatur dalam peraturan perundang-undangan di Indonesia dan SHPTU juga harus memenuhi unsur jaminan yang berupa hak kebendaan. Namun, jika dilihat dari sisi hukum jaminan, SHPTU dapat memenuhi syarat sebagai benda jaminan, sebagaimana pendapat dari Dr. Salim, S.H., M.S. syarat benda yang dapat di jadikan jaminan adalah:

a) Dapat secara mudah membantu perolehan kredit oleh pihak yang memerlukannya.

b) Tidak melemahkan potensi (kekuatan) si pencari kredit untuk melakukan atau meneruskan usahanya.

Memberikan kepastian kepada si kreditur dalam arti bahwa barang jaminan setiap waktu bersedia untuk setiap waktu dieksekusi, bila perlu dapat mudah diuangkan untuk melunasi hutangnya si penerima (pengambil) kredit (R. Subekti, 2010).

Penulis mencoba untuk menganalisis, apakah SHPTU dapat diikat dengan jaminan hak kebendaan:

1) Gadai

Berdasarkan ketentuan pasal 1150 KUH Perdata, yang dimaksud gadai adalah Suatu hak yang diperoleh seorang berpiutang atas suatu barang bergerak yang diserahkan kepadanya oleh seorang berutang atau oleh seorang lain atas namanya, dan yang memberikan kekuasaan kepada si berpiutang itu untuk mengambil pelunasan dari barang tersebut secara didahulukan daripada orang-orang berpiutang lainnya. 
2) Hipotik

Ketentuan pasal 1162 KUH Perdata merumuskan pengertian Hipotik sebagai berikut: "Hipotik adalah suatu hak kebendaan atas benda-benda tak bergerak, untuk mengambil penggantian dari padanya bagi pelunasan suatu perikatan." Dengan kata lain Hipotik adalah hak kebendaan yang member kekuasaan langsung atas benda tak bergerak yang mana benda itu dapat dijadikan jaminan pelunasan sejumlah utang.

3) Hak Tanggungan

Hak Tanggugan diatur dalam Undang-Undang Nomor 4 tahun 1996 tentang Hak Tanggungan atas Tanah Beserta Benda-Benda yang berkaitan dengan tanah (selanjutnya disebut Undang-Undang Hak Tanggungan). Berdasarkan ketentuan pasal 1 angka 1 Undang-Undang Hak Tanggungan, Hak Tanggungan adalah hak jaminan yang dibebankan pada hak atas tanah sebagaimana dimaksud dalam Undang-Undang Nomor 5 tahun 1960 tentang Peraturan Dasar Pokok-Pokok Agraria, berikut atau tidak berikut bendabenda lain yang merupakan satu kesatuan dengan tanah itu, untuk pelunasan utang tertentu yang memberikan kedudukan yang diutamakan kepada kreditur tertentu terhadap kreditur-kreditur lain.

4) Fidusia

Adapun yang dimaksud dengan Jaminan Fidusia, pasal 1, angka 2 Undang-Undang Fidusia memberikan pengertian sebagai berikut: Jaminan Fidusia adalah hak jaminan atas benda bergerak baik yang berwujud maupun tidak berwujud dan benda tidak bergerak khususnya bangunan yang tidak dapat dibebani Hak Tanggungan sebagaimana dimaksud dalam UndangUndang Nomor 4 Tahun 1996 Tentang Hak Tanggungan yang tetap berada dalam penguasaan Pemberi Fidusia, sebagai agunan bagi pelunasan utang tertentu, yang memberikan kedudukan diutamakan kepada Penerima Fidusia terhadap kreditur lainnya (Pratidina, 2018).

Sebagaimana telah disampaikan sebelumnya bahwa Perumda Pasar jaya menginginkan SHPTU dapat diikat dengan fidusia. Adapun pertimbangan adalah Jaminan Fidusia dapat memberikan jaminan kebendaan kepada bank selaku kreditur sehingga dapat melindungi kepentingan bank dan memberikan hak-hak kebendaan kepada bank, termasuk menjalankan parate executie pada saat debitur wanprestasi. Perumda Pasar Jaya menganggap bahwa SHPTU adalah jaminan hak kebendaan, dalam hal ini benda bergerak yang tidak berwujud, Pertimbangan lainnya adalah karena hak pakai kios juga memiliki sifat-sifat kebendaan karena dapat dialihkan berdasarkan Persetujuan dari Direksi Perumda Pasar Jaya.

Undang-Undang Fidusia tidak secara tegas mengatur hak pakai atas bangunan sebagai obyek Jaminan Fidusia dalam hal ini menimbulkan kesalahpahaman di lapangan mengenai kemungkinan hak pakai atas bangunan sebagai obyek Jaminan Fidusia. 
Berdasarkan uraian tersebut terkait SHPTU di Pasar, maka penulis berpendapat bahwa tempat usaha di Pasar yang dimiliki oleh Perumda Pasar Jaya tersebut merupakan izin untuk memakai bangunan, tidak ada hak kepemilikannya. bahwa terdapat risiko apabila pengikatan jaminan SHPTU atas tempat usaha dilakukan dengan pranata jaminan Fidusisa karena kedudukan hak pakai kios sebagai obyek jaminan Fidusia tidak didukung dengan landasan hukum ataupun alasan yang kuat. Sehingga, penjelasan dari keempat lembaga jaminan di atas, dapat diberikan suatu kesimpulan bahwa sebuah tempat usaha Pasar yang diberikan oleh pemerintah setempat, tidak dapat dijaminkan menggunakan keempat bentuk lembaga jaminan di atas.

\section{Sistem Hukum Jaminan}

Dari kajian berbagai literatur tentang hukum perdata, menunjukan bahwa system pengaturan hukum, dapat dibedakan menjadi dua macam, yaitu (Rahmadi, 2009):

a. Sistem tertutup (closed system)

b. Sistem terbuka (open system)

Sistem pengaturan hukum jaminan adalah system tertutup (closed system). Yang diartikan dengan system tertutup adalah orang tidak dapat mengadakan hak jaminan baru, selain yang telah ditetapkan oleh Undang-Undang.

Mengingat sistem pengaturan hukum jaminan sifatnya tertutup, maka penulis berpendapat bahwa Ketentuan tentang jaminan hanya tunduk kepada ketentuan yang sudah ditetapkan sebagaimana tersebut di atas dan diluar ketentuan tersebut ketentuan jaminan tidak tunduk. Oleh karenanya ketentuan SHPTU yang didasarkan dari Peraturan Daerah Khusus Ibukota Jakarta Nomor 3 tahun 2009 tentang pengelolaan Area Pasar tidak dapat diberlakukan dalam hukum jaminan di Indonesia.

\section{Penggunaan SHPTU Sebagai Jaminan Kredit Dalam Praktek}

Sejak dikerluakan Peraturan Otoritas Jasa Keuangan Republik Indonesia Nomor 33/POJK.03/2018 Tentang Aset Produktif dan Pembentukan Penyisahan Pengahapusan asset Produktif Bank Perkreditan Rakyat yang diundangkan pada tanggal 28 Desember 2018, Lembaran Negara Republik Indonesia Tahun 2018, Nomor 258 (selanjutnya disebut POKJ RI No. 33/POJK.03/2018 ), Bank-bank, terutama Bank Perkreditan Rakyat mulai mau menerima SHPTU sebagai jaminan kredit, karena dalam POKJ RI No. 33/POJK.03/2018 pasal 17 ayat 1 (g) menyatakan bahwa "50 \% (lima puluh persen) dari harga pasar, harga sewan, atau harga pengalihan, untuk agunan berupa tempat usaha yang disertai bukti kepemilikan atau surat izin pemakaian atau hak pakai atas tanah yang dikeluarkan oleh instansi berwenang dan disertai dengan surat kuasa menjual atau pengalihan hak yamg dibuat atau disahkan oleh notaris atau dibuat oleh pejabat lain yang berwenang". 


\section{SHPTU Memiliki Kesamaan dengan Sewa Menyewa}

Berdasarkan ketentuan pasal 1548 KUH Perdata, yang dimaksud dengan sewa menyewa adalah suatu perjanjian dengan mana pihak yang satu mengikatkan dirinya untuk memberikan kepada pihak yang lain kenikmatan dari suatu barang selama waktu tertentu dengan pembayaran sesuatu harga yang oleh pihak terakhir disanggupi pembayarannya (Tamengge, 2019).

Melihat ketentuan sewa tersebut diatas maka penulis dapat menyimpulkan adanya kemiripan SHPTU dengan sewa menyewa sebagai berikut:

a. Adanya penyerahan barang dari pemilik kepada penyewa dan pembayaran uang sewa

b. Perumda Pasar Jaya sebagai pemilik bangunan (tempat usaha/kios) menyerahkan hak pemakaian tempat usaha kepada pemilik SHPTU (pedagang) untuk dipakai usaha, sedangkan pedagang (pemilik SHPTU) harus membayar kepada Perumda Pasar Jaya (yang dalam hal ini pembayaran diberikan kepada developer sebagai pihak yang ditunjuk oleh Perumda Pasar Jaya) sejumlah uang atas penjualan hak pemakaian tersebut, demikian disebutkan dalam Peraturan Daerah Provinsi Khusus Ibukota Jakarta Nomor 7 Tahun 2018 tentang Pengelolaan Area Pasar, pasal 1 ayat 11.

c. Adanya pembatasan jangka waktu SHPTU dibatasi jangka waktu sesuai dengan jangka waktu yang tertera dalam SHPTU atau paling lama 20 (dua puluh) tahun, sebagaimana pengertian SHPTU dalam Peraturan Daerah Provinsi Daerah Khusus Ibukota Jakarta, Nomor 7 Tahun 2018 tentang Pengelolaan Dan Pengembangan Usaha Perusahaan Umum Daerah Pasar Jaya pasal 1 ayat (33).

d. Penyewa berkewajiban menjadi "Bapak Rumah Yang Baik". Pemilik SHPTU (Pedagang) berkewajiban menjaga, memelihara tempat usaha dengan baik, tidak merombak, menambah, mengubah, memperluas tempat usaha, serta tidak mengubah jenis jualan.

Berdasarkan hal-hal tersebut diatas, tampak jelas bahwa antara sewa menyewa dengan SHPTU memiliki kesamaan, yang membedakan adalah dasarnya. Sewa Menyewa dasarnya adalah buku III KUH Perdata dan perjanjian antara pemilik barang dengan penyewa, sedangkan SHPTU dasarnya adalah Peraturan Provinsi Daerah Khusus Ibukota Jakarta Nomor 7 Tahun 2018, peraturan lainnya dan perjanjian yang melibatkan 3 (tiga) pihak yaitu, pedagang pasar, developer dan Perumda Pasar Jaya.

B. Kekuatan Pembuktian Sertifikat Hak Pemakaian Tempat Usaha (SHPTU) Dan Sertifikat Tanah Sebagai Jaminan Utang

1. Hubungan Hukum antara Perusahaan Umum Daerah Pasar Jaya, Pedagang dan Developer

Perusahaan Umum Daerah Pasar Jaya yang selanjutnya disebut Perumda Pasar Jaya adalah Perusahaan Umum Daerah Pasar jaya Provinsi Daerah Khusus Ibukota Jakarta, memiliki tugas untuk melaksanakan pelayanan umum dalam 
bidang pengelolaan area pasar milik Pemerintah Provinsi Dearah Khusus Ibu Kota Jakarta. Dalam menjalankan tugas dan fungsinya, Perumda Pasar Jaya diberi kewenangan untuk memfasilitasi kerjasama wadah para pedagang dalam kemitraan dengan pihak lain seperti bekerjasama dengan Pihak Ketiga, dalam hal ini di Pasar Tanah Abang Blok B, Developer sebagai Pihak Ketiga adalah Pihak yang ditunjuk oleh Perumda Pasar Jaya, hal demikian ditegaskan dalam Surat Keputusan Gubernur Daerah Khusus Ibukota Jakarta Nomor 39 Tahun 2002 tentang Ketentuan Pelaksanaan Kerja Sama Perusahaan Daerah Khusus Ibukota Jakarta.

Jadi dalam hal ini, jika para pedagang di Pasar Tanah Abang Blok B ingin memiliki SHPTU atas tempat usaha pasar Tanah Abang Blok B, pedagang memesan tempat usaha kepada Developer sebagai pihak yang ditunjuk oleh Perumda Pasar Jaya, dengan membayar harga jual yang telah ditentukan oleh Developer, lalu pedagang menandatangai Surat Konfirmasi Unit Pesanan dan Surat Pemesanan, setelah pasar Tanah Abang Blok B selesai dibangun dan siap untuk ditempati, para pedagang yang akan menempati kios terlebih dahulu pedagang menandatangani Berita Acara Serah Terima (BAST). Dalam hal pedagang belum melunasi pembayaran atas harga pemakaian tempat usaha kepada Developer, pedagang juga menandatangani Perjanjian Pinjam Pakai Unit Tempat Usaha. Setelah pedagang telah melunasi seluruh pembayaran atas harga pemakaian tempat usaha kepada Developer maka pedagang menandatangani Perjanjian Pemakaian Tempat Usaha (PPTU) dengan Developer dan Perumda Pasar Jaya.

2. SHPTU Merupakan Bukti Kepemilikan atas Hak Pemakaian Tempat Usaha (Fuady, 2020)

Sertifikat Hak Pemakaian Tempat Usaha (SHPTU) adalah bukti kepemilikan hak pemakaian tempat usaha. Seseorang belum dapat memperoleh SHPTU yang diterbitkan oleh Perumda Pasar Jaya selaku pemilik bangunan pasar, manakala belum melunasi seluruh pembayaran harga pengikatan serta biaya-biaya lain yang telah disepakati. Untuk itu, jika bangunan telah siap untuk dipakai dan pembayaran belum lunas, biasanya pihak developer/pengelola mengijinkan pemesan memakai kios untuk berjualan dengan terlebih dahulu menandatangani perjanjian pinjam pakai kios dengan syarat dan ketentuan yang disepakati.

Berdasarkan Peraturan Daerah Provinsi Daerah Khusus Ibukota Jakarta, Nomor 7 Tahun 2018 tentang Pengelolaan Dan Pengembangan Usaha Perusahaan Umum Daerah Pasar Jaya, pada pasal 1 ayat (33) menyatakan: "Sertifikat Hak Pemakaian Tempat Usaha adalah Bukti Kepemilikan atas hak Premakaian Tempat Usaha yang berlaku untuk jangka waktu paling lama 20 (dua puluh) tahun." Dan Pasal 7 ayat (6) menyatakan: "Sertifikat Hak Pemakaian Tempat Usaha dapat dijadikan agunan (Febriyanti, 2020)." 
Dari bunyi pasal tesebut, ada kata "kepemilikan" dan "hak pemakain". Dari kata kepemilikan seolah-olah SHPTU merupakan hak kebendaan, namum jika dilihat hak pemakaian seolah-olah SHPTU sebagai hak perorangan.

Yang menjadi dasar Perumda Pasar Jaya menyatakan bahwa SHPTU sebagai hak kebendaan adalah sebagai berikut:

a) Hak pemakaian tempat usaha di pasar-pasar PD Pasar Jaya diberikan oleh pemerintah DKI Jakarta cq. PD Pasar Jaya kepada para pedagang pasar \pm 62.617 orang dengan jumlah tempat usaha sebanyak \pm 100.000 tempat usaha (yang tersebar di 151 pasar) berpedoman Peraturan Daerah Propinsi DKI Jakarta Nomor 6 tahun 1992 (pasal 9 ayat 2) jo. Peraturan Daerah DKI Jakarta Nomor 12 tahun 1999.

b) Hak tersebut diberikan untuk jangka waktu paling lama 20 tahun dengan cara perolehan melalui penebusan harga jual hak pemakaian tempat usaha kepada PD Pasar Jaya.

c) Berkaitan dengan hal dimaksud pada butir 2 dan sesuai dengan ketentuan Peraturan Daerah beserta pelaksanannya Hak Pemakaian Tempat Usaha pada bangunan pasar PD Pasar Jaya dapat dimiliki dan dialihkan dan dapat dijadikan jaminan kredit. Hal ini sudah berjalan sejak terbitnya Peraturan Daerah Nomor 6 Tahun 1982.

d) Sehubungan dengan hal-hal tersebut di atas, maka Hak Pemakaian Tempat Usaha merupakan kebendaan bergerak yang tidak berwujud atas tempat usaha yang mempunyai nilai ekonomis yang didirikan di atas tanah yang bukan milik, HGB dan HGU tetapi di atas Hak Pakai.

Lebih lanjut (Darus Badrulzaman, 2015), menyatakan bahwa yang menjadi sifat-sifat hak kebendaan adalah sebagai berikut:

1) Bersifat statis.

2) Bersifat absolut, artinya mempunyai akibat kebendaan, yaitu dapat dipertahankan terhadap setiap orang. Hak tersebut mengikuti bendanya di tangan siapa benda itu berada (zaasgevolg, droit de suite).

3) Asas hak prioritas, artinya hak kebendaan memiliki hak didahulukan berdasrkan saat terjadinya hak tersebut.

4) Hak kebendaaan dapat dalam dipindahkan dalam bentuk peralihan lepas, dijaminkan dan dialihkan secara terbatas (hak manfaat).

5) Hak kebendaan menganut sistem tertutup, artinya hak kebendaan tidak dapat didasarkan pada perjanjian.

Menunjuk butir a tersebut diatas, berdasarkan Sumber: PD Pasar Jaya 2019, jumlah pasar dikelola Perumda Pasar Jaya sebanyak 153 Pasar yang tersebar diseluruh wilayah Provinsi DKI Jakarta.

Berdasarkan hal-hal tersebut diatas, Penulis berpandangan bahwa SHPTU bukan hak kebendaan, sebab:

a. Hak Pemakaian Tempat Usaha adalah hak yang bukan termasuk hak yang diatur dalam Buku II KUH Perdata. 
b. SHPTU bukan merupakan kepemilikian bangunan (kios) di Pasar, melainkan bukti kepemilikan atas hak pemakaian Tempat Usaha. Pedagang yang diberikan hak pemakaian tempat usaha oleh Perumda Pasar Jaya hanya berhak untuk memakai, karena pada dasarnya pemilik bangunan tempat pasar (kios) di pasar adalah Pemerintah Provinsi Daerah Khusus Ibukota Jakarta yang dikelola oleh Perumda Pasar Jaya, hal demikian sesuai dengan:

1) Peraturan Daerah Provinsi Daerah Khusus Ibukota Jakarta Nomor 7 Tahun 2018 tentang Pengelolaan Dan Pengembangan Usaha Perusahaan Umum Daerah Pasar Jaya:

a) Pasal 1 ayat (11) yang menyatakan:

Pasar adalah Lembaga ekonomi tempat bertemunya pembeli dan penjual, baik secara langsung maupun tidak langsung, untuk melakukan transaksi perdagangan.

b) Pasal 1 ayat (12) yang menyatakan:

Pengelolaan Usaha Perusahaan Umum Daerah Pasar Jaya adalah pengelolaan Unit Usaha Pasar Jaya yang dikelola dan menjadi kewenangan Perusahaan Umum Daerah Pasar jaya berdasarkan ketemtuan Peraturan Daerah.

c) Pasal 1 ayat (13) yang menyatakan:

Pengembangan Usaha Perusahaan Umum Daerah Pasar Jaya adalah pengembangan Unit Usaha Perusahaan Umum Daerah Pasar Jaya sesuai dengan kebutuhan Perusahaan.

d) Pasal 1 ayat (14) yang menyatakan:

Area Pasar adalah area dalam Pasar yang dikelola dan menjadi yang diperuntukan Perusahaan Umum Daerah Pasar jaya sebagai zona yang diperuntukan bagi berbagai kegiatan yang terintegrasi dengan usaha pasar baik berupa kegaiatn hunian, perdagangan, jasa dam perkantoran.

2) Surat Ijin Pemakaian Tempat Usaha (SIPTU) yang dikeluarkan oleh Direksi Perusahaan Umum Daerah Pasar Jaya diperuntukan kepada para pedagang pasar yang menyatakan pedagang pasar diberikan ijin hanya memakai atas tempat usaha di pasar bukan memiliki, "Untuk memakai tempat usaha milik Perusahaan Umum Daerah Pasar Jaya.

\section{Peraturan Provinsi Daerah Khusus Ibukota Jakarta Nomor 7 Tahun 2018} Tidak Dapat Mengikat Bank dan Jaminan Utang

Meskipun Peraturan Provinsi Daerah Khusus Ibukota Jakarta Nomor 7 Tahun 2018 tentang Pengelolaan Dan Pengembangan Usaha Perusahaan Umum Daerah Pasar Jaya menyatakan bahwa SHPTU adalah bukti kepemilikan yang dapat dijadian agunan, namun dalam kenyataannya Bank tidak serta merta dapat menerima SHPTU sebagai jaminan utang, kalaupun diterima hanya ditempatkan sebagai jaminan tambahan. 
Kekuatan Pembuktian Sertifikat Hak Pemakaian Tempat Usaha (Shptu) Sebagai Jaminan Utang (Contoh Kasus Shptu Pasar Tanah Abang Blok B Jakarta)

\section{Peraturan Daerah Tidak Dapat Mengatur Bank Dan Jaminan Utang}

Peraturan Provinsi Daerah Khusus Ibukota Jakarta Nomor 7 Tahun 2018 secara hukum hanya dapat berlaku di Daerah Khusus Ibukota Jakarta saja dan tidak bisa diberlakukab di luar daerah Jakarta. Sementara itu, bank adalah badan usaha yang memiliki usaha bukan hanya di wilayah Jakarta melainkan di seluruh wilayah Indonesia. Oleh karenanya penulis berpendapat bahwa bank dan ketentuan jaminan utang tidak bisa diatur dengan menggunakan ketentuan Peraturan Daerah, melainkan harus diatur oleh undang-undang.

\section{Sertipikat Sebagai Bukti Kepemilikan Hak Atas Tanah}

a. Sertipikat Sebagai Tanda Bukti Hak

Sertipikat menurut Pasal 1 Peraturan Pemerintah Nomor 24 Tahun 1997 adalah surat tanda bukti hak sebagaimana dimaksud dalam pasal 19 ayat (2) huruf c UUPA untuk hak atas tanah, hak pengelolaan, tanah wakaf, hak milik atas satuan rumah susun dan hak tanggungan yang masing-masing sudah dibukukan dalam buku tanah yang bersangkutan (Susanto, 2014).

\section{Kesimpulan}

Berdasarkan uraian pada bab-bab sebelumnya dan analisis yang telah diuraikan dimuka, dapat diambil kesimpulan sebagai berikut:

Pengertian Sertifikat Hak Pemakaian Tempat Usaha (SHPTU) yang tercantum dalam Peraturan Daerah Provinsi Daerah Khusus Ibukota Jakarta Nomor 7 Tahun 2018 tentang Pengelolaan dan Pengembangan Usaha Perusahaan Umum Daerah Pasar Jaya (Perumda Pasar Jaya) yang menyatakan bahwa SHPTU adalah bukti kepemilikan hak pemakaian tempat usaha yang berlaku untuk jangka waktu paling lama 20 (dua puluh) tahun yang bisa dijadikan jaminan utang, seolah-olah SHPTU memiliki hak kebendaan, sedangkan ditinjau dari Hukum Kebendaan SHPTU bukanlah hak kebendaan. Penulis berpandangan bahwa SHPTU bukanlah merupakan hak kebendaan, sebab hak pemakaian tempat usaha tidak dibahas dalam buku II KUH Perdata dan SHPTU lahir karena adanya Perjanjian Pemakaian Tempat Usaha (PPTU) dan yang menjadi pemilik (gedung) tempat usaha di Pasar Tanah Abang Blok B bukanlah pemilik SHPTU melainkan Pemerintah Provinsi Daerah Khusus Ibukota Jakarta yang dikelola oleh Perumda Pasar Jaya. Sedangkan Pedagang Pasar Tanah Abang Blok B hanya memiliki hak pemakaian tempat usaha di Pasar Tanah Abang Blok B untuk jangka waktu tertentu dengan kewajiban membayar hak pemakaian tersebut dan kewajiban lain yang di tetapkan oleh Perumda Pasar Jaya. Selanjutnya jika dicermati lebih jauh, dapat terlihat bahwa SHPTU memiliki kesamaan unsur dengan sewa menyewa sebagaimana diatur dalam Pasal 1548 KUH Perdata yaitu adanya penyerahan barang dari pemilik kepada penyewa untuk dinikmati (bukan untuk dimiliki), adanya pembayaran harga dari penyewa kepada pemilik serta adanya jangka waktu.

Sertifikat Hak Pemakaian Tempat Usaha (SHPTU) tidak mempunyai kekuatan hukum pembuktian yang sama seperti halnya sertipikat tanah walaupun sama-sama bisa dialihkan ke pihak lain dan tidak semua Bank mau menerima sebagai jaminan utang, 
bahkan tanah dengan Sertipikat Hak Pakai saja hanya bank tertentu yang mau menerima sebagai jaminan walaupun jelas dalam Undang-Undang Republik Indonesia Nomor 4 tahun 1996 Tentang Hak Tanggungan Atas Tanah Beserta Benda-Benda Yang Berkaitan Dengan Tanah (Undang-Undang No 4 Tahun 1996) memperbolehkan Hak Pakai sebagai jaminan. Penulis berpendapat bahwa SHPTU tidak dapat dijadikan jaminan utang dengan pranata jaminan yang sudah ada, meskipun Peraturan Daerah Provinsi Daerah Khusus Ibukota Jakarta Nomor 7 Tahun 2018 menyatakan bahwa SHPTU dapat dijadikan jaminan. Sebab SHPTU tidak dapat dijadikan obyek jaminan dengan menggunakan hukum jaminan kebendaan baik dalam bentuk Gadai, hipotek, hak tanggungan atau jaminan Fidusia. 
Kekuatan Pembuktian Sertifikat Hak Pemakaian Tempat Usaha (Shptu) Sebagai Jaminan Utang (Contoh Kasus Shptu Pasar Tanah Abang Blok B Jakarta)

\section{BIBLIOGRAFI}

Darus Badrulzaman, Mariam. (2015). Hukum Perikatan Dalam KUH Perdata Buku Ketiga (Yurisprudensi, Doktrin, Serta Penjelasan). Bandung: Citra Aditya Bakti. Google Scholar

Febriyanti, Susanty. (2020). Perolehan Hak Pemakaian Tempat Usaha yang Belum Terbit Serifikat Hak Pemakaian Tempat Usaha melalui Perjanjian Kredit dengan Jaminan Cover Note (Pemegang Hak dalam Penantian)(Studi Kasus pada Kantor Swamitra Unit Simpan Pinjam Koperasi Pasar Cipulir). Pamulang Law Review, 3(2), 117-126. Google Scholar

Fuady, M. (2020). Teori Hukum Pembuktian Pidana Dan Perdata (Cetakan Ke). In Pt Citra Aditya Bakti. Bandung: PT. Citra Aditya Bakti. Google Scholar

Khairi, Ilman, \& Roestamy, Martin. (2017). Pengembangan Model Asas Droit De Preference Terhadap Kepemilikan Tempat Usaha Pada Pasar Tanah Abang Jakarta. Jurnal Hukum De'rechtsstaat, 3(2). Google Scholar

Pratidina, Ginung. (2018). Fidusia Sebagai Lembaga Jaminan Atas Tagihan Kredit Pemilikan Rumah Pada Pasar Sekunder. Rechtsregel: Jurnal Ilmu Hukum, 1(1). Google Scholar

R. Subekti. (2010). Hukum Perjanjian. Jakarta: Jakarta: PT Intermasa.

Rahmadi, Usman. (2009). Hukum Jaminan Keperdataan. Jakarta: Sinar Grafika. Google Scholar

Salim, H. S., \& Nurbani, Erlies Septiana. (2017). Penerapan Teori Hukum pada Penelitian Tesis dan Disertasi Buku Kedua. PT Raja Grafindo Persada: Depok. Google Scholar

Soerjono Soekanto. (2019). Pengantar Penelitian Hukum. Jakarta: UI Press. Google Scholar

Soerjono Soekanto dan Sri Mamudji. (2019). Penelitian Hukum Normatif Suatu Tinjauan Singkat. Depok: Rajawali Pers.

Susanto, Bronto. (2014). Kepastian Hukum Sertifikat Hak Atas Tanah Berdasarkan Peraturan Pemerintah Nomor 24 Tahun 1997. DiH: Jurnal Ilmu Hukum, 10(20). Google Scholar

Tamengge, Miranda. (2019). Kajian Yuridis Tentang Sewa Menyewa Sebagai Perjanjian Konsensuil Berdasarkan Pasal 1548 KUHPerdata. Lex Privatum, 6(7). Google Scholar 
Liana P Nugroho, Gunawan Djajaputra

\section{Copyright holder:}

Liana P Nugroho dan Gunawan Djajaputra (2021)

First publication right:

Journal Syntax Literate

This article is licensed under:

(c) (1) (2) 